- DOI: $10.31866 / 2410-1311.38 .2021 .247176$

удк 316.775:379.8]:[316.774:159.9]-049.5

\title{
ДОЗВІЛЛЄВІ ПРАКТИКИ ОСОБИСТОСТІ У МЕДІАПРОСТОРІ: ПРОБЛЕМИ ІНФОРМАЦІЙНО-ПСИХОЛОГІЧНОЇ БЕЗПЕКИ
}

\section{- Матвієнко Оксана Володимирівна ${ }^{1 a}$, Цивін Михайло Наумовиче2b, Новальська Тетяна Василівна ${ }^{3 a}$, Бачинська Надія Анатоліївна ${ }^{4 a}$}

- ' 'Доктор педагогічних наук, кандидат технічних наук, професор,

ORCID: 0000-0001-5772-848X, e-mail: oxmix2017@gmail.com,

${ }^{2}$ Кандидат технічних наук, доцент,

ORCID: 0000-0003-0312-5805, e-mail: tsyvin2012@gmail.com,

${ }^{3}$ Доктор історичних наук, професор,

ORCID: 0000-0003-3093-3998, e-mail: novalska@meta.ua,

${ }^{4}$ Кандидат педагогічних наук, доцент,

ORCID: 0000-0003-3912-7108, e-mail:n.bachynska17@gmail.com,

аКиївський національний університет культури і мистецтв,

вул. Є. Коновальця, 36, Київ, Україна, 01133

${ }^{\mathrm{b}}$ /нститут дизайну, архітектури та журналістики,

вул. Фрометівська, 2, корп. 2, Київ, Україна, 03039

\section{- Для цитування:}

Матвієнко, О.В., Цивін, М.Н., Новальська, Т.В., \& Бачинська, Н.А. (2021). Дозвіллєві практики особистості у медіапросторі: проблеми інформаційно-психологічної безпеки. Питання культурології, (38), 314-333. doi: https://doi.org/10.31866/2410-1311.38.2021.247176.

\section{- Анотація}

Мета статті - дослідити медіапростір та охарактеризувати основні підходи до інформаційно-психологічної безпеки в контексті медіавпливу у дозвіллєвих практиках особистості. Методологія дослідження полягає у використанні соціального та аксіологічного підходів, що дозволило розглядати поняття «медіапростір дозвілля» як соціально-психологічний феномен, який здійснює безпосередній вплив на психологію особистості. Наукова новизна. Проаналізовано поняття медіапростору, «агресивного» медіасередовища; запропоновано робоче визначення медіабезпеки особистості як основної складової інформаційно-психологічної безпеки; визначено зміст медіаосвіти. Висновки. Доведено, що людина, знаходячись у сформованому сучасними медіа просторі зазнає інформаційних впливів, які трансформують її поведінку, психіку, світосприйняття та подекуди здійснюють маніпулювання психологією. Наголошено на необхідності медіабезпеки особистості як основної складової інфрормаційно-психологічної захищеності у сучасних умовах, зважаючи на те, що молодь сьогодні $є$ глобальною медіааудиторією, 
а використання медіа $€$ важливою частиною дозвілля. Визначено, що одними із найважливіших складових інформаційно-психологічної безпеки $€$ медіавиховання та медіаосвіта, завданням яких $є$ формування у людини критичного мислення для свідомого споживання медіапродукції, адекватного оцінювання інфрормації та здатності протистояти зовнішній інформаційній агресії і пропаганді, деструктивним медіаінформаційним впливам. Інтеграція медіаосвіти у роботі з молоддю $є$ не тільки природним кроком, а й потребою розвитку окремого напряму педагогіки дозвілля — медіапедагогіки дозвіллєвої діяльності.

Ключові слова: медіапростір; медіабезпека особистості; дозвіллєва практика; медіапедагогіка дозвіллєвої діяльності; медіапсихологія

\section{Вступ}

Використання людиною вільного часу нерозривно пов'язане із медіаресурсами. Сучасні соціальні медіа пропонують не тільки новий формат взаємин між відправником і одержувачем інформації, а й створюють нове медійне середовище, яке має неформальний характер, відкриває перед кожною людиною можливості для активності, творчої самореалізації у дозвіллєвій діяльності, надає засоби для створення і публікації власних презентацій, статей, інтерв'ю, фрільмів, фотографрій, аудіо. Перетворившись на головний засіб суспільно-політичного та культурного життя сучасні медіа створюють «медіареальність», яка відіграє ключовий вплив на свідомість та може змінити поведінку людини. У медіапросторі подекуди застосовуються методи маніпулювання свідомістю для досягнення власних цілей (владних і впливових структур та безпосередньо самих ЗМІ), неприйнятних для особистості ідеалів та цінностей. Про гостроту проблеми маніпулювання масовою свідомістю свідчить те, що сьогодні вже йдеться про консциєнтальну зброю і консциєнтальну війну, котрі руйнують певні типи і форми організації свідомості, на місце яких стає штучно сконструйована матриця цінностей, правил поведінки і реакцій.

Тому для сучасного суспільства актуальною постає проблема інформаційно-психологічної безпеки особистості у медіапросторі. А основним засобом «захисту» людини, забезпечення її медіабезпеки є медіаосвіта. Саме завдяки медіаграмотності особистість має можливість не тільки адаптуватися та перетворювати реалії медіапростору, а й виступати активним суб'єктом позитивних змін у сорері медіавпливів.

Наголосимо, що нині дозвіллєву діяльність у медіапросторі варто позначити як інформальну, тобто таку, яка супроводжує повсякденне життя, не має цілеспрямованого характеру, є спонтанною, реалізується через власну активність людини у навколишньому медіасередовищі. Однак суттєвим результатом такої діяльності $€$ сформульована М. Чурсіним (2016) теза про те, що «... у процесі "вільного становлення" людина-особистість поступово переходить від ситуації розвитку (хаотичного пізнання світу) до ситуації управління, яке супроводжується усвідомленням і постановкою цілей» (с. 47).

Проблемі медіавпливів та інформаційно-психологічної безпеки у медіапросторі присвячено чимало досліджень закордонних та вітчизняних науковців. Так, українські дослідники розглядали комунікативну діяльність у мережі 
Інтернет, її вплив на особистісні зміни у юнацькому віці, формування життєвих планів, девіантність молоді з інтернет-залежністю та ін. Зокрема, соціалізація студентської молоді у процесі використання можливостей мережі Інтернет розглянута у роботі О. Матвієнко та Г. Остапенко (2013). Зроблено висновок щодо необхідності їі керованого характеру і зниження елементів стихійності, створення умов для ефективного засвоєння соціальних впливів, які здійснюються у процесі комунікативної діяльності цією соціальною групою у мережі Інтернет. Дослідження, присвячені комунікативній діяльності студентської молоді знаходимо у Л. Компанцева (2007). У розвідці запропоновано заходи інформаційної роботи закладів вищої освіти зі студентами - організація цілодобового доступу до інформаційних ресурсів, їх своєчасне якісне наповнення, соціальна спрямованість. Звертається увага на можливі небезпеки культурних трансформацій особистості у процесі інтернет-комунікацій студентської молоді, зокрема на лінгвокультурологічні аспекти, формування нових ознак мовної особистості та мовної картини світу.

Щодо проблем безпеки особистості у медіапросторі зазначимо, що їх теоретичне дослідження у вітчизняному науковому дискурсі розпочалося з поняття «інформаційна безпека». Було вироблено певною мірою узгоджені підходи до його розуміння, зокрема розмежовано поняття «інфрормаційна безпека» та «безпека інформації», диверсифіковано застосування терміна у гуманітарному та техніко-технологічному контекстах. Наголосимо, що науковий пошук переважно був спрямований на виявлення загроз інформаційній безпеці держави, суспільства або ж на безпеку використання засобів мережі Інтернет.

Осмислення медіапростору у полі досліджень дозвіллєвої діяльності сьогодні відбувається у напрямі вивчення впливу мережі Інтернет на розвиток особистості, питань інтернет-залежності, безпеки у соціальних медіа, комунікативних практик. Ці питання досліджено І. Соловйовою (2007) (девіантність особистості в умовах комп'ютеризації суспільства), В. Фатуровою (2004) (комунікативний потенціал студентів-користувачів інтернет-середовища та особливості його цілеспрямованого фрормування і розвитку). У роботі М. Назар (2010) наголошується, що інтернет-спілкування $є$ чинником змін психологічних особливостей особистості в юнацькому віці. Пропонуються психологічно обґрунтовані засоби з метою організації психологічного впливу на особистісні утворення користувачів, зокрема студентів закладів вищої освіти - інтернет-тренінги для нейтралізації певних психологічних особливостей постійних користувачів інтернет-сайтів, підвищення їх самоактуалізації, креативності, комунікативності. Психологічною наукою вивчається вплив мережі Інтернет на формування такого соціального явища, як життєвий план молоді з інтернет-залежністю (Посохова, 2006). Загалом дослідники роблять висновок про те, що надмірне перебування молоді у мережі спричинює неадекватне сприймання подій віртуального життя внаслідок некритичного ставлення особистості до кіберсередовища та розвитку залежної від нього поведінки.

Проблеми, присвячені конкретним аспектам спілкування у мережі Інтернет знаходимо також у російських дослідників А. Мелешнікова та М. Рижкова. Зокрема, це дослідження, де предметом виступає психологічний зміст, детермінанти і ефекти сприйняття особистості незнайомої людини за фротографрією при 
спілкуванні в мережі Інтернет (Мелешников, 2010), специфріка та особливості мовних стратегій учасників синхронного інтернет-дискурсу (Рыжков, 2010) та ін. Зміст, поширеність та диференціацію соціальних інтернет-практик користувачів в умовах інформаційного суспільства виявлено у роботі А. Радкевича (2009). У його дослідженні подано авторське бачення поняття «соціальні інтернет-практики» і запропоноване таке їх визначення: «Соціальні інтернет-практики являють собою сукупність рутинних дій та звичних способів поведінки, пов'язаних із використанням мережі для розв'язання проблем та/або підвищення ефективності діяльності у різних сфрерах життя, а також для задоволення різних потреб». У розвідці Д. Коваленка (2012) запропоновані організаційні шляхи формування інфоормаційно-комунікативної культури молоді у системі вищої освіти. Застосовуючи культурологічні та соціологічні концепції становлення інформаційного суспільства, автор виявляє чинники, які впливають на необхідність своєчасної адаптації навчального процесу та позанавчальної роботи закладів вищої освіти до сучасного рівня масової комунікації.

\section{- Мета статті}

Мета статті - дослідити медіапростір та схарактеризувати основні підходи до інформаційно-психологічної безпеки в контексті медіавпливу у дозвіллєвих практиках особистості.

\section{- Виклад матеріалу дослідження}

Поняття «медіапростір» не $є$ остаточно визначеним і однозначно зрозумілим. Ширше за змістом поняття «інфрормаційний простір» визначають як сукупність результатів семантичної діяльності людини. Інформаційний простір охоплює банки і бази даних, технології їх супроводу і використання, технології, які забезпечують інфоормаційну взаємодію організацій та громадян і дають змогу задовольнити їхні інформаційні потреби. Загалом основними компонентами інформаційного простору є інформаційні ресурси, засоби інформаційної взаємодії та інформаційна інфрраструктура.

Поняття «медіапростір» з'явилось пізніше, однак зберігає основні складові поняття «інформаційний простір». Зокрема, у Вікіпедії наводиться визначення поняття «медіапростір», яке умовно назвемо діяльнісним і технологічно орієнтованим: «...електронні умови, в яких групи людей можуть працювати разом, навіть якщо вони не знаходяться в одному й тому ж самому місці в один і той самий час. У медіапросторі люди можуть створювати візуальні та звукові середовища, які охоплюють фізично розподілені площини. Вони також можуть контролювати запис, доступ і відтворення зображень і звуків у цих середовищах» ("Медіапростір", 2020).

Сучасні трактування медіапростору, погляди на його сутність узагальнено та інтегровано у такий спосіб (Монастырёва, 2010): $3 \mathrm{MI})$;

- ядром медіапростору визнаються засоби масової комунікації (зокрема

- своєю чергою 3MI (а отже, медіапростір) є активним актором формування інших видів просторів: соціального, культурного, освітнього, релігійного та ін.; 
- зміни у медіапросторі безпосередньо пов'язані з трансформаційними процесами у суспільстві. Оскільки медіапростір відображає провідні тенденції розвитку суспільства, це дає змогу вивчити його розвиток у контексті перетворень, які відбуваються у суспільстві;

- медіапростір формує картину світу, яка знаходиться поза межами чуттєвого досвіду індивіда. Медіапростір - це не просто відображення реальності, це - соціально конструйоване розуміння світу;

- медіапростір є складною системою, що має певний набір структурних елементів, які взаємопов'язані і підпорядковуються загальним закономірностям розвитку цілого.

Зазначимо, що наведене узагальнення сутності медіапростору, його визначення як активного актора формування інших видів просторів та картини світу особистості дає змогу зробити крок до того, щоб тлумачити медіапростір дозвіллєвої діяльності як простір соціального конструювання розуміння світу особистості у процесі реалізації нею дозвіллєвих практик.

Безперечно, поняття «медіапростір» безпосередньо пов'язане з поняттям «інформаційного середовища». Не зупиняючись на аналізі та узагальненні наявних підходів до визначення їх співвідношення, наведемо запропоноване К. Калюжним (2015) визначення інформаційного середовища як антропогенної частини простору, у якому взаємодіють і самоорганізуються суб'єкти і об'єкти інформаційних процесів, що підтримуються інформаційною інфраструктурою і пов'язані з пошуком, обробкою і зберіганням інформації. Умовами комфортної роботи в інфрормаційному середовищі є можливість корегування інформаційної потреби, легкість використання, відсутність суттєвих та несподіваних ускладнень, легкість освоєння. Водночас наголос на антропологічній складовій акцентує «суб'єктивність» інформаційного середовища і кореспондується із відомим у системі інформаційної діяльності поняттям «комфортності інфрормаційного середовища», введеним Ю. Шрейдером (2008).

Застосовуючи поняття «комфортність» у його початковому значенні, як: умови, обставини, котрі сприятливо впливають на самопочуття, діяльність кого-небудь; добре самопочуття, настрій, яке створюється такими умовами, обставинами, все ж визнаємо, що відчуваючи комфортність, людина у медіапросторі може заразом зазнавати впливів, які руйнують ії̈ особистість, змінюють установки і нав'язують стереотипи. Адже сучасні медіа, перетворившись на основний засіб суспільно-культурного та політичного життя не тільки показують процеси, що відбуваються у суспільстві, а й формують вид «вторинної» реальності - так звану медіареальність, інформаційний вплив якої на свідомість мислення, почуття та емоційну сферу людей, не поступається об'єктивній реальності.

Отже, комунікативні технології впливу відіграють ключову роль на свідомість і поведінку масової аудиторії. Під впливом медіа — як традиційних, так і новітніх, масова аудиторія часто отримує суперечливі та несистематизовані повідомлення. Різноманітність джерел інформації та інтересів, які вони переслідують, породжує інформаційне протиборство, що може мати вирішальний вплив на психоемоційний стан особистості. Внаслідок багатьох чинників їхні функції 
трансформуються, повідомлення подекуди відображають неадекватну і нереалістичну картину сучасного світу, що становить потенційну загрозу руйнування моральних і етичних норм, культурних та художніх цінностей. Застосовуючи маніпулятивні технології, засоби масової комунікації змінюють поведінку людей, нав'язують стереотипи та соціальні міфи. Тому діалогічність соціальних медіа, обмін контентом, можливість пошуку однодумців і набуття навичок створення соціальних зв'язків, медіаактивізм (схожий з організаторською функцією традиційних $3 \mathrm{MI}$ ) повинні розглядатися не тільки у позитивному контексті. Адже сьогодні суспільно-політичний простір характеризується надзвичайною щільністю текстів, подій та повідомлень маніпулятивного характеру, що призводить до актуалізації у людини «синдрому інформаційної втоми» - інформаційних перевантажень, які негативно впливають на її здоров'я.

Людина як особистість і як активний соціальний суб'єкт, знаходячись у медіапросторі зазнає впливів інформаційних чинників, що трансформують її поведінку, психіку, світосприйняття, часом здійснюючи й дисфункціональний вплив. Інколи медіакартина світу являє собою продукт соціального маніпулювання психологією масової аудиторії, який ускладнює адекватне пізнання об'єктивної реальності. Витончені методи, що застосовуються з метою маніпулювання свідомістю, утвердження неприйнятних для особистості ідеалів та цінностей, можуть змінити поведінку людини, спрямовуючи її не тільки на недостойні, а й на суспільно неприйнятні вчинки.

Внаслідок низки різноманітних заходів і дій можуть змінюватися переконання, світогляд і трансформуватися інші елементи особистісної структури людини, зокрема:

- руйнування наявної структури особистості;

- зменшення почуття безпеки, індукування страху і тривоги;

- провокування деградації уявлення про себе;

- провокування сильного почуття провини;

- доведення особистості до стану регресії.

3-поміж заходів і дій психологічного тиску в інтернет-середовищі згадаємо тролінг — фрорму соціальної провокації або знущання у мережевому спілкуванні та кібербулінг (кібермобінг) - цькування, залякування, умисні загрози, дифамації, повідомлення іншим скомпрометованих даних.

Серед можливих наслідків такого психологічного тиску - зменшення здатності до критичного мислення, утруднення внутрішньої концентрації, інфрантилізація особи, стимулювання штучних потреб, зниження рівня самоповаги і виникнення почуття провини, відчуття власного безсилля, негативне уявлення про себе, що зумовлює зменшення власної активності і відмову від життєвих завдань. Відчуття безпорадності і залежності від обставин чи інших осіб зумовлюють виникнення оборонних механізмів так званої регресії.

3 огляду на вищезазначене цілком конструктивною визнається сьогодні концепція «агресивного медіасередовища»; а повідомлення у ньому активують негативні емоційні реакції та стани (Петрунько, 2011). Для людини, яка має проблеми у навчанні, неуспішну соціалізацію, дисгармонійний, травмований емоційний світ, будь-який вплив може мати непередбачувані реакції. I якщо 
вплив (зокрема інформаційний) побудовано на використанні сили примітивних інстинктивних реакцій, така людина буде легко керованою (Коваленко Н. П. \& Коваленко А. А., 2018).

Дослідники питань створення «агресивного» медіапродукту з-поміж інших причин називають замовлення владних і впливових структур та комерційний інтерес власне самих ЗMІ. Особливо багато претензій висувається до засобів масової інформації та журналістів, які часом демонструють непрофесіоналізм, підміняють журналістську діяльність пропагандою, агітацією та відвертими маніпуляціями суспільною свідомістю, нав'язують утопічні конструкції, міфоологізують події та явища. У нинішньому комунікативному середовищі завдяки ЗМІ процес створення міфів значно прискорився і став одним з основних засобів психологічної війни. Створювана 3MI картина світу із цілісної та узгодженої стає для особи фррагментарною, мозаїчною, складеною з набору міфрів, які дають неправдиву, викривлену картину світу і часто примушують людей діяти всупереч своїм інтересам. Сьогодні вже йдеться про індустрію міфотворчості - етнокультурної, історичної, політичної.

Технології засобів масової комунікації стимулюють процес виникнення і розвитку нових антропологічних стратегій, які заміщують традиційні механізми формування свідомості (конфресійні, культурно-історичні, етнонаціональні, культурно-історичні, державні) посттрадиційними механізмами - віртуалізація культурного процесу, антропологічні стратегії розпаду, руйнування ідентичності, масифікація.

Зокрема, сьогодні уже предметно досліджується таке явище, як медіаненависть (Циганов, 2016) - цілеспрямоване, планомірне, систематичне використання можливостей засобів масової інформації (масмедіа) для створення, тиражування, поширення та отруєння почуттями страху й ненависті в інформаційному просторі та громадській свідомості. У поєднанні з відомим у сфері психології масових комунікацій «синдромом друкованого слова», який характеризується впевненістю індивіда у достовірності джерела інформації, явище медіаненависті є потужним руйнівним інструментом свідомості людини.

Про гостроту проблеми маніпулювання масовою свідомістю свідчить руйнація певних типів і форм організації свідомості, на місце яких стає штучно сконструйована матриця цінностей, правил поведінки і реакцій завдяки використанню консциєнтальної зброї і веденню консциєнтальних воєн.

Медіасередовище визнається агресивним й до дітей, наголошується на необхідності формування адаптаційно-захисного потенціалу соціалізації (Петрунько, 2010). У категоріях «інформаційної соціалізації» та «медіасоціалізації» аналізуються соціально-психологічні наслідки комунікації у соціальних мережах та їх змістовий вплив на процес підліткової соціалізації (Белинская, 2013).

Так, нагальною потребою для суспільства постає медіабезпека, адже проблема безпеки особистості в інформаційному просторі локалізується у полі діяльності медіа, і на часі вже - дослідження медіабезпеки особистості як основної складової інформаційно-психологічної безпеки у сучасних умовах.

Нами було запропоноване таке робоче визначення медіабезпеки особистості (Цивін \& Матвієнко, 2015): 
Медіабезпека особистості - це такий стан людини, коли дія медіаповідомлень і реакція на них не призводить до погіршення функціонування і розвитку організму, свідомості, психіки особи загалом і не перешкоджає досягненню певних бажаних для людини цілей.

Визнаючи ключовим змістом психоемоційну рівновагу особистості, вважаємо доцільним також звернутися до напрацювань одного з узагальнених наукових напрямів у галузі досліджень впливу медіа на особистість - медіапсихології. Дослідники, вивчаючи предметну сферу та завдання медіапсихології, визначають її як галузь науки, яка позиціонується на перетині психології та соціальних комунікацій (Бутиріна, 2012). Медіапсихологія виступає як теорія і практика протидії маніпуляції; вивчає співвідношення індивідуальної та колективної психіки, індивідуальної та масової свідомості, індивідуального і масового підсвідомого. До взаємопов'язаних прикладних напрямів медіапсихології дослідники відносять медіааналітику, медіатерапію і медіаосвіту.

Медіааналітика досліджує контент медіакомунікації з погляду дотримання принципів інформаційно-психологічної безпеки; виявлення психотехнологій масових інфрормаційних кампаній та їхніх наслідків; психологічні, юридичні і етичні аспекти журналістської діяльності.

Медіатерапія розробляє системи і способи психологічного захисту від патогенних інформаційних технологій, програми профрілактики і реабілітації інформаційних травм аудиторії та ін.

Основним завданням медіаосвіти, яка визнається педагогічною наукою окремим напрямом педагогіки, $є$ розширення знань аудиторії про основні засоби впливу 3МІ, що підвищує рівень адаптованості та інформаційно-психологічної захищеності учасників масової комунікації.

Ці три складові - медіааналітика, медіатерапія та медіаосвіта - разом утворюють стратегію і базовий ресурс медіапсихологічного захисту соціуму і людини.

Однією із найважливіших складових у загальній структурі простору соціалізації підлітків та юнацтва, які знаходяться у процесі становлення ідентичності стає медіавиховання. I хоча певні заходи державних органів, суспільства, педагогічної спільноти із забезпечення безпеки особистості у полі дії сучасних медіа здійснюються, однак вони не мають системного характеру та потребують удосконалення. Не дають бажаних результатів й спроби правового регулювання медіапростору для обмеження небажаних впливів на молодь. Йдеться не про різноманітні заборони, а насамперед про системні заходи з розвитку критичного мислення особистості. Сучасна людина повинна навчитися самостійно орієнтуватись у медіасередовищі, бути медіакомпетентною - мати здатність критично аналізувати та оцінювати медіатексти, аналізувати складні процеси функціонування медіа у суспільстві.

Водночас для навчання, виховання і дозвілля визначальним є той факт, що у медіасередовищі одночасно наявна інформація, яка об'єктивно відображає існуючий світ, так і деформована інформація (дезінформація). Тому перед суспільством виникає проблема погодження структурних ланок освіти з ознаками культури, адекватної розвитку інформаційного суспільства. Значною мірою цей 
стан відображає спостереження, зроблене свого часу відомим американським футурологом А. Тофрлером (1997), який розмірковуючи про зміни, які відбуваються і будуть відбуватись у суспільстві, звертаючись до проблем освіти, наголошував: «І все-таки попри всю цю риторику щодо майбутнього, наші школи повертаються до зникаючої системи, а не рухаються вперед до нового суспільства, яке виникає. Їхня значна енергія спрямована на підготовку Індустріальних Людей - людей, екіпірованих для виживання у системі, яка припинить своє існування раніше, ніж вони».

Сьогодні педагогіка має формувати свої ресурси, виходячи з проблем соціуму, у якому існує і розвивається людина. На часі навчання і виховання людини, включно з «соціальною ситуацією її розвитку» (за Л. Виготським), з урахуванням як позитивних, так і негативних впливів суспільних процесів на людину і суспільство. До цієї ситуації можна також застосувати відому у соціології та критичній педагогіці ідеологію «прихованого навчального плану» або «латентної програми» (hidden curriculum), зокрема у тій частині, яка стосується латентної трансмісії культурних цінностей, норм, диспозицій, установок, цілеспрямованого формування певного типу особистості.

Отже, медіаосвіта як окремий напрям педагогічної науки і практики $є$ не лише методологічно визнаною, а й такою, що може вважатись основним засобом «захисту» особистості, забезпечення ії медіабезпеки. Цей специфічний напрям освіти сформувався у педагогічній науці у другій половині XX ст. у провідних країнах світу і був покликаний допомогти школярам і студентам краще орієнтуватись у світі медіакультури, освоїти мову засобів масової інфоомації, навчитись аналізувати медіатексти.

Один 3 авторитетних медіапедагогів і теоретиків медіа Л. Мастерман (L. Masterman) обґрунтував необхідність пріоритетності й актуальності медіаосвіти у сучасному світі, назвавши такі основні чинники (цит. за: Федоров, 2007):

- високий рівень споживання медіа і насиченості сучасного суспільства засобами масової інформації;

- ідеологічна важливість медіа як галузі промисловості та їх впливу на свідомість аудиторії;

- швидке зростання медійної інформації, посилення механізмів управління нею та її поширення;

- інтенсивність проникнення медіа в основні демократичні процеси;

- підвищення значущості візуальної комунікації та інформації в усіх галузях;

- необхідність навчання школярів / студентів з орієнтацією на відповідність майбутнім вимогам;

- зростання національних та міжнародних процесів приватизації інформацiï.

Вітчизняна педагогічна наука також уважно ставиться до питань медіаосвіти. Так, ще 21 березня 2016 р. Президією Національної академії педагогічних наук України було схвалено нову редакцію Концепції впровадження медіаосвіти в Україні.

Одним з основних завдань медіаосвіти у Концепції (MediaSapiens, 2016) визначено рефлексію і критичне мислення як психологічні механізми, що забез- 
печують свідоме споживання медіапродукції і саморегуляцію взаємодії з медіа на основі ефективного орієнтування в медіапросторі та осмислення власних медіапотреб, адекватного та різнобічного оцінювання змісту, джерела, фрорми і якості надання інформації, ії̈ повноцінного і критичного тлумачення з урахуванням особливостей сприймання мови різних медіа; розвивають здатність протистояти зовнішній інформаційній агресії і пропаганді, деструктивним медіаінфрормаційним впливам.

Дослідники поділяють медіаосвіту на кілька основних напрямів (Демидов, 2016):

- медіаосвіта майбутніх і нинішніх професіоналів - журналістів, кінематографрістів, редакторів;

- медіаосвіта майбутніх і нинішніх педагогів у 3ВО, системі підвищення кваліфікації;

- медіаосвіта як частина загальної освіти школярів і студентів, яка може бути інтегрованою з традиційними дисциплінами або автономною (спеціальною, фракультативною, у гуртках);

- медіаосвіта у закладах додаткової освіти та дозвіллєвих центрах;

- дистанційна медіаосвіта школярів, студентів та дорослих за допомогою радіо, телебачення, мережі Інтернет (значну роль тут відіграє медіакритика);

- самостійна / безперервна медіаосвіта, яка здійснюється упродовж усього життя.

В сучасному світі здатність критично оцінювати медіатексти, розуміти їх джерела, політичні, соціальні, комерційні й культурні інтереси, відрізняти факти, які потребують перевірки, адекватно оцінювати інформацію і фрормулювати власну думку й визначати свою позицію $є$ нагальною потребою. Розуміючи під критичним мисленням систему суджень, яка використовується для аналізу подій із фрормулюванням обґрунтованих висновків і дає змогу виносити обґрунтовані оцінки, інтерпретації, а також коректно застосовувати одержані результати до ситуацій і проблем, вважаємо, що розвиток критичного мислення є основою медіабезпеки особистості.

На необхідність формування навичок безпечного використання медіа звертають увагу міжнародні організації та науковці всіх країн. Зокрема, Фінське товариство медіаосвіти у співробітництві з Інститутом ЮНЕСКО з інформаційних технологій видало підручник «Педагогічні аспекти фрормування медійної та інфрормаційної грамотності» (Туоминен \& Котилайнен, 2012), у якому ці питання розглядаються, зокрема й у зв'язку з дозвіллям молоді та підлітків.

Автори підручника наголошують, що акцентуючи у медіаосвіті на стратегіях безпечної поведінки, а не на аналізі медіаконтенту, ми фрормуємо лише елементарний рівень медіаграмотності.

Натомість навички критичного аналізу медіа передбачають:

- розуміння різниці між фрактом і вигадкою, рекламою та іншими видами медіаконтенту:

- знання різних жанрів та наративних засобів і розуміння того, що зміст медіа залежить від вибору авторів і замовників і може мати різне трактування; 
- здатність аналізувати, оцінювати і контролювати інформацію, знання того, як діють медіа; знайомство зі структурою медіа, здатність розпізнати, що знаходиться під оболонкою медіаконтенту;

- піддавати сумніву повідомлення медіа і розуміти, як працюють стереотипи;

- знання комерційних, політичних та ідеологічних цілей медіа;

- здатність оцінити мету і цільову аудиторію джерел, оцінити ступінь надійності, точності, нейтральності і відкритості представленої інформації.

На нинішньому етапі впливовості медіа очевидним стає, що педагогічна практика має фрормуватися з урахуванням конкретних умов і суперечностей соціального середовища, структур соціальних взаємин, місця і ролі людини, її діяльності у конкретному соціально-історичному середовищі, тобто бути соціально орієнтованою. На зміст освіти, особливо пов'язаний із проблематикою медіавпливів, значною мірою можна екстраполювати таку функцію соціальної педагогіки, як пізнання реальної ситуації життєдіяльності людини, яка проживає в умовах певного соціального середовища і розвивається у конкретних історичних соціокультурних умовах суспільства.

Зважаючи на те, що молодь сьогодні $є$ глобальною медіааудиторією, а використання медіа $є$ важливою частиною дозвілля молодих людей, не тільки інтеграція медіаосвіти у роботу з молоддю є природним кроком, а на часі розвиток окремого напряму педагогіки дозвілля - медіапедагогіки дозвіллєвої діяльності. Однак актуальність досліджень у проблемному полі медіапростору дозвілля зумовлена низкою суперечностей між:

- необхідністю забезпечення медіабезпеки особистості під час реалізації нею дозвіллєвих практик та відсутністю структурно і за змістом організованої системи формування критичного мислення на всіх рівнях та ступенях освіти;

- зростанням значення проблем психологічної безпеки особистості у полі впливу сучасних медіа, необхідністю адекватного сприйняття інформації особистістю, критичного її оцінювання і недостатнім рівнем осмислення цих проблем у проблемному полі педагогіки дозвілля, відсутністю адекватних інструментів та засобів формування відповідних компетенцій особистості.

Очевидно, що педагогіка дозвілля потребує побудови теорій, концепцій і моделей, розробки педагогічно обґрунтованої системи організації дозвілля сучасної молоді і відповідно педагогічної моделі її організації, а також соціально-педагогічної та соціально-психологічної підтримки особистості у медіапросторі дозвіллєвої діяльності. Реалізація педагогічного процесу у сфері дозвілля передбачає і реалізацію таких цілей, як забезпечення цілісного впливу на всі особистісні фрактори та перетворення навчання на органічну чистину життя.

Трансформаційні процеси, які відбуваються у змісті та формах організації дозвіллєвої діяльності потребують переосмислення і корегування сутності її змісту у напрямі взаємопроникнення культурної, освітньої та інформаційної сфер суспільного життя, що виводить проблему змісту дозвіллєвої діяльності на поліфункціональний рівень.

Дозвіллєві практики особистості у медіапросторі в контексті проблем інформаційно-психологічної безпеки є багатовимірним, мають взаємопов'язані складові, які потребують свого визначення — це і поняття «медіапростір дозвілля», 
розкриття його сутності і зв'язку із соціально-педагогічними та виховними аспектами дозвіллєвої діяльності. Педагогіка дозвілля розкриває закономірності складного та багатогранного дозвіллєвого процесу, в якому індивіду відводиться активна роль; вона визначається вченими як одна з наук про людину, про виховання та розвиток особистості у вільний час. Дозвіллєва діяльність є виховним процесом із певною структурою, змістом та принципами, в якому увага педагога спрямована на систематичний виховний процес організації діяльності особистості і переведення її на вищий рівень розвитку.

Наведемо висловлювання відомого британського медіапедагога Д. Букінгема (Buckingham, D.), який робить висновок (цит. за: Федоров, 2007), що епоха інформаційного суспільства призвела до «... появи нової парадигми медіаосвіти. ... Вона не починається з того, що медіа обов'язково і неминуче є шкідливими, або що молоді люди - просто пасивні жертви впливу медіа. ... Медіаосвіта не намагається захистити молодих людей від впливу медіа, але дає можливість учням приймати обґрунтовані рішення щодо їхнього власного захисту. Медіаосвіта бачиться не формою захисту, а фрормою підготовки». У контексті цього висловлювання наведемо визначення медіаосвіти, яке видається найбільш вдалим і таким, що висвітлює сутність медіаосвіти як основи безпечного існування людини у медіапросторі (Федоров, 2012): медіаосвіта (media education) - процес розвитку особистості за допомогою і на матеріалі засобів масової комунікації (медіа) з метою формування культури спілкування з медіа, творчих, комунікативних здатностей, критичного мислення, повноцінного сприйняття, інтерпретації, аналізу і оцінки медіатекстів, навчання різним фрормам самовираження за допомогою медіатехніки, набуття медіаграмотності. Однак особистість унаслідок досягнення цілей медіаосвіти повинна не тільки адаптуватися до реалій медіапростору, а перетворювати ці реалії, виступати як активний суб'єкт позитивних змін у сорері медіавпливів на особистість.

\section{Висновки}

Отже, сучасні медіа не тільки показують процеси, що відбуваються у суспільстві, а й фрормують «медіареальність», інформаційний вплив якої на свідомість не поступається об'єктивній реальності. Медіапростір трансформує поведінку, психіку, світосприйняття, часом здійснюючи маніпулювання психологією масової аудиторії, що ускладнює адекватне пізнання об'єктивної реальності. Тому нагальною потребою для суспільства постає медіабезпека, завдяки якій дія медіаповідомлень не призводить до погіршення функціонування свідомості, психіки і людини загалом і не перешкоджає досягненню певних цілей. А одними із найважливіших складових інформаційно-психологічної безпеки стають медіавиховання та медіаосвіта, основним завданням яких є критичне мислення для свідомого споживання медіапродукції і саморегуляції взаємодії з медіа на основі ефективного орієнтування в медіапросторі та осмислення власних медіапотреб, адекватного оцінювання інфрормації та здатності протистояти зовнішній інформаційній агресії і пропаганді, деструктивним медіаінформаційним впливам.

Очевидно, що в інформаційному суспільстві освіта втрачає звичні моделі трансляції знань та зразків і потребує пошуків нової парадигми, яка передбачає 
орієнтацію на розвиток особистості. Криза освіти сьогодні розглядається у контексті загальносвітової тенденції становлення постіндустріальної культури як наступного етапу культурогенези, що супроводжується глобальними катаклізмами, викликаними конфрліктом між відмираючою цивілізацією індустріалізму та народжуваною цивілізацією постіндустріалізму. Тобто сутність кризи сучасної освіти - вичерпаність культурної адекватності освітньої парадигми, створеної для індустріальної культури. Отже, перед суспільством виникає проблема погодження структурних ланок освіти з ознаками культури, адекватної розвитку інфрормаційного суспільства. Тому для педагогічної теорії важливим $€$ формування на базі інфоомаційно-цивілізаційних підходів наукового пошуку, спрямованого на побудову нової моделі безперервної освіти.

Доведено, що на часі постає необхідність дослідження медіабезпеки особистості як основної складової інформаційно-психологічної захищеності у сучасних умовах, зважаючи на те, що молодь сьогодні є глобальною медіааудиторією, а використання медіа $€$ важливою частиною дозвілля. Інтеграція медіаосвіти у роботі з молоддю $є$ не тільки природним кроком, а й потребою розвитку окремого напряму педагогіки дозвілля — медіапедагогіки дозвіллєвої діяльності.

\section{- Список використаних джерел}

Белинская, Е. П. (2013). Информационная социализация подростков: опыт пользования социальными сетями и психологическое благополучие. Психологические исследования, 6(30), 5. http://psystudy.ru/index.php/num/2013v6n30/858belinskaya30.html

Бутиріна, М.В. (2012). Медіапсихологія: до питання формування навчальної дисципліни. Ученые записки Таврического национального университета им. В. И. Вернадского. Серия «Филология. Социальные коммуникации», 25(64), 4(1), 85-90.

Демидов, А. А. (2016). Развитие неформального, инфрормального и медиаобразования для целей развития критического мышления и фрормирования информационной безопасности личности. Управленческое консультирование, 2(86), 113-119.

Калюжный, К.А. (2015). Информационная среда и информационная среда науки: сущность и назначение. Управление наукой и наукометрия, (18), 7-23.

Коваленко, Д. Г. (2012). Формирование информационно-коммуникативной культуры молодежи в системе высшего образования [Автореферат диссертации кандидата социологических наук, Российская академия народного хозяйства при Президенте Российской Федерации].

Коваленко, Н. П., \& Коваленко, А. А. (2018, 16 мая). Информационнаяикоммуникационная манипуляция и массовое сознание. В Е. В. Федосенко, \& Л. Ф. Уварова (Ред.), Актуальные вопросы экономики, права, психологии и образования, Материалы Всероссийской научно-практической конференции (с. 19-24). Санкт-Петербург, Россия. https://www.elibrary.ru/item.asp?id=35374808

Компанцева, Л. Ф. (2007). ІІнтернет-комунікація: когнітивно-прагматичний та лінгвокультурологічний аспекти [Автореферат дисертації доктора фрілологічних наук, Інститут мовознавства ім. О. О. Потебні Національної академії наук України]. 
Литвин, Н. (2013, 31 октября - 2 ноября). Профрессионально ориентированная медиапсихология в медиаподготовке будущих редакторов. В И. В. Жилавская (Ред.), Медиаобразование 2013: Сборник трудов Международного форума конференций (с. 294-303). Редакционно-издательский центр Московского государственного гуманитарного университета им. М. А. Шолохова.

Матвієнко, О. В., \& Остапенко, Г.І. (2013). Комунікативна діяльність у мережі Інтернет: теоретико-методологічні підходи до аналізу соціалізації студентської молоді. Вісник Харківської державної академії культури, 41, 151-158.

Медіапростір. (2020, 22 лютого). В Вікіпедіï. https://uk.wikipedia.org/wiki/Медіапростір.

Мелешников, А. А. (2010). Восприятие личности по фоотографрии при общении в Интернет (на материале сайтов знакомств) [Автореферат диссертации кандидата психологических наук, Ярославский государственный университет им. П. Г. Демидова].

Монастырёва, О.В. (2010). Медиапространство: обзор представлений и подходов к пониманию. Вестник Амурского государственного университета, 50(40), 56-62.

Назар, М. М. (2010). Інтернет-спілкування як чинник особистісних змін у юнацькому віці [Авторефрерат дисертації кандидата психологічних наук, Інститут психології ім. Г. С. Костюка НАПН України].

Петрунько, О. В. (2010). Діти і медіа: соціалізація в агресивному медіасередовищі [Монографія]. Укрпромторсервіс.

Петрунько, О. В. (2011). Агресивне медіасередовище: якісний і змістовий дискурси. Рідна мова, (16), 36-43.

Посохова, В. В.(2006). Соціально-психологічні особливості фрормування життєвих планів Інтернет-залежної молоді [Автореферат дисертації кандидата психологічних наук, Інститут соціальної та політичної психології АПН України].

Пронин, Е. И., \& Пронина, Е. Е. (2013). Медиапсихология: новейшие информационные технологии и феномен человека. Общественные науки и современность, (2), $151-162$.

Радкевич, А. Л. (2009). Социальные интернет-практики как объект социологического анализа. Знание. Понимание. Умение, 3. http://www.zpu-journal.ru/e-zpu/2009/3/ Radkevich/

Рыжков, М. С. (2010). Речевые стратегии участников синхронного интернет-дискурса (на материале русско- и англоязычных чатов) [Автореферат диссертации кандидата фрилологических наук, Воронежский государственный университет].

Соловйова, І.І. (2007). Девіантність особистості в умовах комп'ютеризації суспільства: соціально-фрілософрський аспект [Авторефрерат дисертації кандидата фрілософрських наук, Південноукраїнський державний педагогічний університет ім. К. Д. Ушинського].

Тофрер, А. (1997). Футурошок. http://psihdocs.ru/toffler-a-futuroshok-per-s-angl-spb-1997464-s.html

Туоминен, С., \& Котилайнен, С. (2012). Педагогические аспекты фрормирования медийной и информационной грамотности. Институт ЮНЕСКО по информационным технологиям в образовании. https://iite.unesco.org/pics/ publications/ru/files/3214708.pdf 
Фатурова, В. М. (2004). Інтернет-середовище як фрактор психологічного розвитку комунікативного потенціалу особистості [Авторефрерат дисертації кандидата психологічних наук, Інститут психології ім. Г. С. Костюка АПН України].

Федоров, А. В. (2007). Развитие медиакомпетентности и критического мышления студентов педагогического вуза [Монография]. Издательство МОО ВПП ЮНЕСКО «Информация для всех». https://www.researchgate.net/ publication/278516436_Razvitie_mediakompetentnosti_i_kriticeskogo_myslenia_ studentov_pedagogiceskogo_vuza.

Федоров, А. В. (2012). Медиаобразование. В Большая российская энциклопедия (Т. 17, С. 480). Большая российская энциклопедия.

Цивін, М. Н., \& Матвієнко, О. В. (2015). Медіабезпека особистості як соціально-освітня проблема. Вісник Національної академії керівних кадрів культури і мистецтв, (2), 195-200.

Циганов, В. В.(2016). Феномен медіа-ненависті в контексті національної безпеки. Стратегічна панорама, (2), 84-89.

Чурсин, Н. Н. (2016, 12-13 травня). Системы образования и научной коммуникации в контексте социальной информатики. В М. В. Макарова (Ред.), Структурні зміни у суспільстві та економіці під впливом комунікацій та інфрормації, Матеріали Міжнародної науково-практичної конференції. Полтава, Україна (c. 44-48). Полтавський університет економіки і торгівлі.

Шрейдер, Ю.А. (2008). Информационные процессы и информационная среда. Научнотехническая инфрормация. Серия 2. Информационные процессы и системы, (9), 3-7.

MediaSapiens. (2016, 27 квітня). Концепція впровадження медіаосвіти в Україні (нова редакція). https://ms.detector.media/mediaosvita/post/16501/2016-04-27kontseptsiya-vprovadzhennya-mediaosvity-v-ukraini-nova-redaktsiya/

\section{- References}

Belinskaya, E. P. (2013). Informatsionnaya sotsializatsiya podrostkov: opyt pol'zovaniya sotsial'nymi setyami i psikhologicheskoe blagopoluchie [Informational socialisation in adolescents: experience of using social networks and psychological wellbeing] Psikhologicheskie Issledovaniya, 6(30), 5. http://psystudy.ru/index.php/ num/2013v6n30/858-belinskaya30.html [in Russian].

Butyrina, M. V. (2012). Mediapsykholohiia: do pytannia formuvannia navchalnoi dystsypliny [Media psychology: to the question of formation of educational discipline]. Uchenye Zapiski Tavricheskogo Natsional'nogo Universiteta im. V. I. Vernadskogo. Seriya "Filologiya. Sotsial'nye Kommunikatsii", 25(64), 4(1), 85-90 [in Ukrainian].

Chursyn, N. N. (2016, May 12-13). Sistemy obrazovaniya i nauchnoi kommunikatsii v kontekste sotsial'noi informatiki [Education systems and scientific communication in the context of social informatics]. In M. V. Makarova (Ed.), Strukturni zminy u suspilstvi ta ekonomitsi pid vplyvom komunikatsii ta informatsii [Structural Changes in Society and the Economy Under the Influence of Communications and Information], Proceedings of the International Scientific and Practical Conference. Poltava, Ukraine (pp. 44-48). Poltava University of Economics and Trade [in Russian].

Demidov, A. A. (2016). Razvitie neformal'nogo, informal'nogo i mediaobrazovaniya dlya tselei razvitiya kriticheskogo myshleniya i formirovaniya informatsionnoi 
bezopasnosti lichnosti [Development of non-formal, informal and media education for the development of critical thinking and formation of information security of the personality]. Upravlencheskoe Konsul'tirovanie, 2(86), 113-119 [in Russian].

Faturova, V. M. (2004). Internet-seredovyshche yak faktor psykholohichnoho rozvytku komunikatyvnoho potentsialu osobystosti [The Internet Environment as a Factor in the Psychological Development of the Communicative Potential of the Individual] [Abstract of PhD Dissertation, G.S. Kostiuk Institute of Psychology of the National Academy of Educational Sciences of Ukraine] [in Ukrainian].

Fedorov, A. V. (2007). Razvitie mediakompetentnosti i kriticheskogo myshleniya studentov pedagogicheskogo vuza [Development of the Media Competence and Critical Thinking of Pedagogical University's Students] [Monograph]. Izdatel'stvo MOO VPP YuNESKO "Informatsiya dlya vsekh". IPOS UNESCO IFAP https://www.researchgate. net/publication/278516436_Razvitie_mediakompetentnosti_i_kriticeskogo_ myslenia_studentov_pedagogiceskogo_vuza [in Russian].

Fedorov, A. V. (2012). Mediaobrazovanie [Media education]. In Bol'shaya rossiiskaya entsiklopediya [Big Russian Encyclopedia] (Vol. 17, p. 480). Bol'shaya rossiiskaya entsiklopediya [in Russian].

Kalyuzhnyi, K. A. (2015). Informatsionnaya sreda i informatsionnaya sreda nauki: sushchnost' i naznachenie [Information environment and information environment of science: essence and purpose]. Upravleniye Naukoy i Naukometriya, (18), 7-23 [in Russian].

Kompantseva, L. F. (2007). Internet-komunikatsiia: kohnityvno-prahmatychnyi ta linhvokulturolohichnyi aspekty [Internet communication: cognitive-pragmatic and linguo-cultural aspects] [Abstract of DSc Dissertation, Potebnia Institute of Linguistics] [in Ukrainian].

Kovalenko, D. G. (2012). Formirovanie informatsionno-kommunikativnoi kul'tury molodezhi $v$ sisteme vysshego obrazovaniya [Formation of Information and Communication Culture of Youth in the Higher Education System] [Abstract of PhD Dissertation, the Russian Presidential Academy of National Economy and Public Administration] [in Russian].

Kovalenko, N. P., \& Kovalenko, A. A. (2018, May 16). Informatsionnaya i kommunikatsionnaya manipulyatsiya i massovoe soznanie [Information and communication manipulation and mass consciousness]. In E. V. Fedosenko, \& L. F. Uvarova (Eds.), Aktual'nye voprosy ekonomiki, prava, psikhologii i obrazovaniya [Actual Issues of Economics, Law, Psychology and Education], All-russian Scientific-practical Conference, (pp. 19-24). St.-Petersburg, Russia. https://www.elibrary.ru/item.asp?id=35374808 [in Russian].

Lytvyn, N. (2013, October 31 - November ). Professional'no orientirovannaya mediapsikhologiya $v$ mediapodgotovke budushchikh redaktorov [Professionally oriented media psychology in the media training of future editors]. In I. V. Zhilavskaya (Ed.), Mediaobrazovanie 2013 [Media Education 2013]: Collected Works of the International forum Conference (pp. 294-303). Editorial and Publishing Center Sholokhov Moscow State University for Humanities [in Russian].

Matviienko, O. V., \& Ostapenko, H. I. (2013). Komunikatyvna diialnist u merezhi Internet: teoretyko-metodolohichni pidkhody do analizu sotsializatsii studentskoi molodi [Communicative activity on the Internet: theoretical and methodological approaches 
to the analysis of socialisation of student youth]. Visnyk of Kharkiv State Academy of Culture, 41, 151-158 [in Ukrainian].

Mediaprostir. (2020, February 22). In Wikipedia. https://uk.wikipedia.org/wiki/Mediaprostir [in Ukrainian].

MediaSapiens. (2016, April 27). Kontseptsiia vprovadzhennia mediaosvity v Ukraini (nova redaktsiia) [The Concept of Introducing Media Education in Ukraine (New Edition)]. https://ms.detector.media/mediaosvita/post/16501/2016-04-27-kontseptsiyavprovadzhennya-mediaosvity-v-ukraini-nova-redaktsiya/ [in Ukrainian].

Meleshnikov, A. A. (2010). Vospriyatie lichnosti po fotografii pri obshchenii v Internet (na materiale saitov znakomstv) [Personality Perception from Photographs When Communicating on the Internet (Based on Dating Sites)] [Abstract of PhD Dissertation, Yaroslavl State University] [in Russian].

Monastyreva, O. V. (2010). Mediaprostranstvo: obzor predstavlenii i podkhodov k ponimaniyu [The Media Space: An Overview of Views and Approaches to Understanding]. Vestnik Amurskogo Gosudarstvennogo Universiteta, 50(40), 56-62 [in Russian].

Nazar, M. M. (2010). Internet-spilkuvannia yak chynnyk osobystisnykh zmin u yunatskomu vitsi [Internet Communication as a Factor of Personal Change in Adolescence] [Abstract of PhD Dissertation, G.S. Kostiuk Institute of Psychology of the National Academy of Educational Sciences of Ukraine] [in Ukrainian].

Petrunko, O. V. (2010). Dity i media: sotsializatsiia $v$ ahresyvnomu mediaseredovyshchi [Children and the Media: Socialisation in an Aggressive media environment] [Monograph]. Ukrpromtorservis [in Ukrainian].

Petrunko, O. V. (2011). Ahresyvne mediaseredovyshche: yakisnyi i zmistovyi dyskursy [Aggressive media environment: qualitative and semantic discourses]. Ridna Mova, (16), 36-43 [in Ukrainian].

Posokhova, V. V. (2006). Sotsialno-psykholohichni osoblyvosti formuvannia zhyttievykh planiv Internet-zalezhnoi molodi [Socio-psychological Features of the Formation of Life Plans of Internet-addicted Youth] [Abstract of PhD Dissertation, Institute for Social and Political Psychology of the National Academy of Educational Sciences of Ukraine] [in Ukrainian].

Pronin, E. I., \& Pronina, E. E. (2013). Mediapsikhologiya: noveishie informatsionnye tekhnologii i fenomen cheloveka [Media psychology: the latest information technologies and the human phenomenon]. Social Sciences and Contemporary World, (2), 151-162 [in Russian].

Radkevich, A. L. (2009). Sotsial'nye internet-praktiki kak ob "ekt sotsiologicheskogo analiza [Internet-based Social Practices as a Subject of Sociological Analysis]. Knowledge. Understanding. Skill, 3. http://www.zpu-journal.ru/e-zpu/2009/3/Radkevich/ [in Russian].

Ryzhkov, M. S. (2010). Rechevye strategii uchastnikov sinkhronnogo internet-diskursa (na materiale russko- $i$ angloyazychnykh chatov) [Speech Strategies of Participants in a Synchronous Internet Discourse (Based on the Material of Russian and Englishlanguage Chats)] [Abstract of $\mathrm{PhD}$ Dissertation, Voronezh State University] [in Russian].

Shreider, Yu. A. (2008). Informatsionnye protsessy i informatsionnaya sreda [Information processes and information environment]. Nauchno-tekhnicheskaya Informatsiya. Seriya 2. Informatsionnye Protsessy i Sistemy, (9), 3-7 [in Russian]. 
Soloviova, I. I. (2007). Deviantnist osobystosti v umovakh komp'iuteryzatsii suspilstva: sotsialnofilosofskyi aspekt [Deviance of Personality in the Conditions of Computerisation of Society: Socio-philosophical Aspect] [Abstract of PhD Dissertation, South Ukrainian National Pedagogical University named after K. D. Ushynsky] [in Ukrainian].

Tofler, A. (1997). Futuroshok. http://psihdocs.ru/toffler-a-futuroshok-per-s-angl-spb-1997464-s.html [in Russian].

Tsyhanov, V. V. (2016). Fenomen media-nenavysti v konteksti natsionalnoi bezpeky [The phenomenon of media hatred in the context of national security]. Strategic Panorama, (2), 84-89 [in Ukrainian].

Tsyvin, M. N., \& Matviienko, O. V. (2015). Mediabezpeka osobystosti yak sotsialno-osvitnia problema [Media security of the individual as a socio-educational problem]. National Academy of Managerial Staff of Culture and Arts Herald, (2), 195-200 [in Ukrainian]. Tuominen, S., \& Kotilainen, S. (2012). Pedagogicheskie aspekty formirovaniya mediinoi $i$ informatsionnoi gramotnosti [Pedagogical Aspects of the Formation of Media and Information Literacy]. Institute for Information Technologies in Education (IITE UNESCO) https://iite.unesco.org/pics/publications/ru/files/3214708.pdf [in Russian].

\section{- LEISURE PRACTICES OF PERSONALITY IN THE MEDIA SPACE: ISSUES OF INFORMATION AND PSYCHOLOGICAL SECURITY}

\section{Oksana Matviienko'a, Mykhailo Tsyvin²b, Tetiana Novalska ${ }^{3 a}$, Nadiia Bachynska ${ }^{4 a}$}

- ${ }^{1} D S c$ in Education, Professor,

ORCID: 0000-0001-5772-848X, e-mail: oxmix2017@gmail.com,

${ }^{2} P h D$ in Technical Sciences, Associate Professor,

ORCID: 0000-0003-0312-5805, e-mail: tsyvin2012@gmail.com,

${ }^{3} \mathrm{DSc}$ in History, Professor,

ORCID: 0000-0003-3093-3998, e-mail: novalska@meta.ua,

${ }^{4} \mathrm{PhD}$ in Education, Associate Professor,

ORCID: 0000-0003-3912-7108, e-mail: n.bachynska17@gmail.com,

${ }^{a}$ Kyiv National University of Culture and Arts,

Kyiv, Ukraine,

bInstitute of Design, Architecture and Journalism,

Kyiv, Ukraine

\section{- Abstract}

The purpose of the article is to determine the media space and distinguish the main approaches to information and psychological security related to the media influence in the leisure practice of a person. The research methodology consists of the use of social and axiological approaches, which allowed us to consider the concept of "leisure media space" as a sociopsychological phenomenon that directly impacts the psychology of a person. Scientific novelty. The article analyses the concepts of media space, "aggressive" media environment; offers 
the code definition of media security of the person as the primary component of information and psychological safety; defines the media education content. Conclusions. It is proved that a person being in the media space formed by modern media undergoes information influences that transform their behaviour, psyche, worldview and sometimes manipulate psychology. We emphasized the need for media security of the individual as a major component of information and psychological security in current conditions, given that young people today are a global media's target audience, and the use of media is an essential part of young people's leisure. It is determined that one of the most critical components of information and psychological security is media mentoring and media education, the task of which is to form critical thinking for conscious consumption of media products, adequate evaluation of information and ability to resist external information aggression and propaganda, destructive media influences. The integration of media education in working with young people is a natural step and the need to develop a separate area of leisure pedagogy - media pedagogy of leisure activities.

Keywords: media space; personal media security; leisure practice; media pedagogy of leisure activities; media psychology

\section{ДОСУГОВЫЕ ПРАКТИКИ ЛИЧНОСТИ В МЕДИАПРОСТРАНСТВЕ: ПРОБЛЕМЫ ИНФОРМАЦИОННО-ПСИХОЛОГИЧЕСКОЙ БЕЗОПАСНОСТИ}

\section{- Матвиенко Оксана Владимировна ${ }^{1 a}$, Цивин Михаил Наумовиче2b, Новальская Татьяна Васильевна ${ }^{3 a}$, Бачинская Надежда Анатольевна ${ }^{4 a}$}

- ' 'Доктор педагогических наук, кандидат технических наук, профрессор,

ORCID: 0000-0001-5772-848X, e-mail: oxmix2017@gmail.com,

2Кандидат технических наук, доцент,

ORCID: 0000-0003-0312-5805, e-mail: tsyvin2012@gmail.com,

З Доктор исторических наук, профрессор,

ORCID: 0000-0003-3093-3998, e-mail: novalska@meta.ua,

${ }^{4}$ Кандидат педагогических наук, доцент,

ORCID: 0000-0003-3912-7108, e-mail:n.bachynska17@gmail.com,

а Киевский национальный университет культуры и искусств,

Киев, Украина,

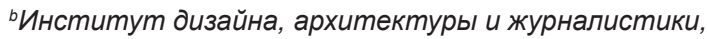

Киев, Украина

\section{- Аннотация}

Цель статьи - исследовать медиапространство и охарактеризовать основные подходы к информационно-психологической безопасности в контексте медиавоздействия в досуговых практиках личности. Методология исследования заключается в использовании социального и аксиологического подходов, что позволило рассматривать понятие «медиапространство досуга» как социально-психологический феномен, оказывающий непосредственное влияние на психологию личности. Научная новизна. Проанализировано 
понятие медиапространства, «агрессивной» медиасреды; предложено рабочее определение медиабезопасности личности как основной составляющей информационнопсихологической безопасности; определено содержание медиаобразования. Выводы. Доказано, что человек, находясь в сформированном современными медиа пространстве испытывает информационные воздействия, которые трансформируют его поведение, психику, мировосприятие и иногда осуществляют манипулирование психологией. Отмечена необходимость медиабезопасности личности какосновной составляющей информационнопсихологической защищенности в современных условиях, учитывая, что молодежь сегодня является глобальной медиааудиторией, а использование медиа является важной частью досуга. Определено, что одними из важнейших составляющих информационнопсихологической безопасности являются медиавоспитание и медиаобразование, задача которых состоит в формировании у человека критического мышления для сознательного потребления медиапродукции, адекватной оценки информации и способности противостоять внешней информационной агрессии и пропаганде, деструктивным медиаинформационным воздействиям. Интеграция медиаобразования в работе с молодежью является не только естественным шагом, но и необходимостью развития отдельного направления педагогики досуга - медиапедагогики досуговой деятельности.

Ключевые слова: медиапространство; медиабезопасность личности; досуговая практика; медиапедагогика досуговой деятельности; медиапсихология 